\title{
Determinants of Customer Trust and Its Implication
}

\author{
Nandan Limakrisna \\ Faculty of Economic \\ Universitas Persada Indonesia YAI, \\ Jakarta, Indonesia. \\ amarta.nandan@gmail.com
}

\author{
Deden Komar Priatna, Winna Roswina \\ Post Graduated Program \\ Universitas Winaya Mukti \\ Bandung, Indonesia \\ dedenkomar@yahoo.com,winnaroswina71@gmail.com
}

\begin{abstract}
The real conditions a Sharia Banking in Bandung, shows that there is a very loyal customer which contributes more than 50 percent of the Moslem. The conditions reinforce the notion that the profit sharing and customer relationship have an influence in determining customer trust and in turn has implications for customer commitment of Sharia Banking in Bandung. The purpose of this research is to know and analyze the effect of profit sharing and customer relationships to customer trust, and its implication on customer commitment. The methods in this research use a quantitative approach to the design of explanatory and cross-sectional time horizon, using primary and secondary data, while the sampling is done by a proportional random sampling method which results in the sample of 210 respondents. The research model using Structural Equation Model (SEM). This finding of the results is Profit sharing and customer relationships proven to have a significant influence on customer trust, and customer trust shown to have a significant influence on customer commitment. The customer relationship is becoming customer consideration for trust and commit to Sharia Bank.
\end{abstract}

Keywords - profit sharing; customer relationships; customer trust; customer commitment.

\section{INTRODUCTION}

The business world in the era of free competition, the company should continue to seek and strengthen the value of the company that makes the value - it has the confidence of its customers (customer trust) [1]. Confidence of customers is the biggest asset for any company, since have a very positive impact and proportional against Sales the company can do. In other words, the greater the confidence of customers it will be getting bigger also level of sales of the company's [2].

Preliminary study on some Sharia banks in the city of Bandung, namely, Bank Muamalat, Bank Syariah Mandiri, and BJB Syariah objects of research on the influence of between the profit sharing, customer relations, and customer trust in maintaining and enhancing customer commitment, generating the identification of the that (a) it is an indication of the customer trust is low, it is seen from a number of Islamic banking clients still under the Conventional Banking, Islamic banking clients in General also have a Bank account in Conventional (b) low customers' trust tends to be caused by the relationship marketing strategies that are less well built (c) low advertising costs and have allegedly been an indication of low consumer trust at Sharia banking (d) profit sharing changing allegedly lose consumer trust (e) profit sharing a dynamic influence on the customers' commitments assumed if the anticipated good customer relations strategy.

Furthermore, based on the identification of the condition of the Islamic banking restrictions to simply explore on factors of profit sharing, customer relationships, customer commitment and trust in Islamic banking customers. By using this restriction, then the outline of the problem each is (a) a whether there is influence between the profit sharing is changing (dynamic profit-sharing) against commitment customers (customer commitment) (b) A whether there is influence between customer relations (customer relationship marketing) on customers' trust (c) a whether there is influence between profit sharing are changing - a change (dynamic profit-sharing) on customer commitments (d) a whether there is influence of customer relations on customer commitment (e) a whether there is influence customers trust on customer commitment at Islamic banking in Bandung.

\section{HOW TO BUILT CUSTOMER COMMITMENT}

Strategy to gain the confidence of customers, among others, is fostered and maintain good relationship with customers, so companies can recognize and understand the needs and wants of its customers [3]. The strategy can be done with the approach of the strategy of relationship marketing, namely the introduction of every customer are closer to creating two-way communication by managing a mutually beneficial relationship between customers and the company [4].

In on it, stated that creating close relationships with customers is the dream of all marketers and became the key to the success of marketing in the long term, primarily through creating customers as the task of the company [5]. The company's Task to create customers by Islamic banking in Bandung, where there are very loyal customers who contribute over 50 per cent, i.e. customers who are Muslim. The condition alleged that the quality of service and internal controls has influence in determining the customers' trust and in turn has implications towards a customer commitment at Sharia Banking in Bandung. But no problem if customers who will transact non-Muslims in Islamic banking, if the customer trust is good.

Pay attention to the formulation of the problem, then the theoretical research done about (1) the profit sharing that change (2) customer relationship (3) customer trust and (4) customer commitment. Based on the research of theoretical 
framework formulation was born thinking in accordance with the formula issue in this study.

\section{RESEARCH METHODOLOGY}

Research it uses a quantitative approach with explanation causal or design that aims to explain how one variable affecting or liable for changes in other variables [6]. Relationships between variables that will be tested in this study is between profit sharing, customer relationship, and trust on customer's commitment.

Further, research is cross-sectional i.e. a type of study that undertake an information collection / questionnaire is only one time in a particular time to sample [7]. Because the data collected simultaneously at a given moment and only once by way of disseminating a questionnaire to the respondent's/consumer's Sharia Banking.

The Data collected to support this research consists of primary data and secondary data. The data is the primary data collected by individuals/organizations directly through the object [8].

The primary data is collected with a questionnaire, deployment techniques the designed for questions concerning the perception of the respondent against profit sharing, customer relationships, commitment to customers, and customer trust Sharia Banking, while secondary data obtained through literature-literature, research journals, magazines, and documents.

This is the entire research Population plunging Sharia Banking (Bank Muamalat, Bank Syariah Mandiri, Bank BJB Syariah), while the sampling done by the method of proportional random sampling, the sample research as much as 210 respondents, the criteria have become customers of Sharia Banking at least 1 year and is domestic customer. Against the questionnaires returned by the respondent conducted measurements of validity in the form of test validity, mainly test the validity of invalid constructs, which measure the extent to which the difference of the observed scale score that reflects the difference between the actual objects on the characteristics that are being measured, rather than systemic error or random error [7]. Reliability measurements are also carried out further questionnaires by using the Cronbach alpha method is measured by Cronbach alpha scale 0 to 1 , to determine whether any instrument reliability or not. With the technique analysis, Structural Equation Models using data "Structural Equation Modelling" (SEM) to assess the hypothesis because it has the ability to estimate a range of relationships and interconnected of the relationship when explaining the error of measurement in the process of estimation [9]. The independent variable is exogenous invalid constructs (non) are not affected by other variables in the model, the $p$ there is this research is profit sharing and customer relations [9]. In the meantime, the endogenous constructs as the dependent variable (not free) that is affected by one or more other variables in the model, which up there is this research there are two endogenous invalid constructs, namely the commitment of customers and customer trust.
Because this research use model of research with Structural Equation Models (SEM), then this model is capable of analyzing the relationship between latent variables with variable charge indicators will, the relationship between latent variables are latent variables one with Iain, also knew the magnitude of error measurements. Besides the causal relationship is unidirectional, SEM also allows to analyze twoway relationship that often appears in social science and behavioral [9].

\section{FINDING \& DISCUSSIONS}

The results of the index test the suitability of the model can be seen in the table the following.

TABLE I. TABle 1 IndeX to Test The Suitability of The Model

\begin{tabular}{|c|c|c|}
\hline Criteria & $\begin{array}{c}\text { The Results } \\
\text { of the Model }\end{array}$ & $\begin{array}{c}\text { The evaluation of } \\
\text { the }\end{array}$ \\
\hline CMIN/DF & 4,329 & Marginal Fit \\
$T L I$ & 0,910 & Marginal Fit \\
RMSEA & 0,070 & Marginal Fit \\
NFI & 0,701 & Marginal Fit \\
\hline
\end{tabular}

CMIN/DF Values of 4, 329 indicates that the above structural model is quite good because it ranges from 2 up to 5 (Marsh and Hocevar, 1985). While the value of 0, RMSEA 0.071 can be considered a model of good, according to Hair et al., (2006) recommended RMSEA value between 0.03 to 0.08 .

Next Tucker Lewis Index (TLI) with a value of 0, 91 is approaching 1 , so that it can be said the model was still very good, because according to [9] the TLI values approaching 1 is a good model. The value of the normed fit index (NFI) of 0,701 approaching 1 proves also that structural model above is a good model [9]. The results of hypothesis testing on this research can be seen in the table the following.

On the hypothesis testing 1 , which stated that there was a significant influence between the variable profit-sharing on customer trust. The results of hypothesis testing showed that the hypothesis is supported because it has a value of loading of 0.67 and a value obtained by 1 CR 5, 295 greater than 1.96. Thus, the results of earlier research supported the results of this research.

Hypothesis testing 2 stating that there is a significant influence between customer relationship on customer trust. The results of hypothesis testing showed that the hypothesis is supported because it has a value of loadings of the CR and the value of 0.81 obtained by 16,141 greater than 1.96 . Thus, the results of earlier research supported the results of this research.

On the hypothesis testing 3 stating that there is a significant influence among profit sharing on customer commitment. The results of hypothesis testing showed that the hypothesis is supported because it has a value of loadings of the $\mathrm{CR}$ value and 0.38 acquired for larger 8.064 of 1.96 . Thus, the results of earlier research supported the results of this research.

Test of hypothesis 4 States that there is a significant influence between customer relationship on customer 
commitment. The results of hypothesis testing showed that the hypothesis is supported because it has a value of loading of $0.85 \mathrm{CR}$ value and that are acquired for larger 12.557 from 1.96. Thus, the results of earlier research supported the results of this research.

The test of hypothesis 5 stating that there is a significant influence between customer trust on customer commitment. The results of hypothesis testing showed that the hypothesis is supported because it has a value of loading of 0,11 and CR values are acquired for 2,101 is bigger than 1.96.

Based on the test results is obtained that the variable profit sharing and customer relationships have significant influence on customer trust. Meanwhile, profit sharing, customer relationships, and customer trust have a significant effect on customer commitment.

Its influence on customer trust, proved to bring customer relationship variables is the most dominant variables affect the commitment of the Sharia Banking customers, where it is seen from the loading values obtained in 0 , i.e. 81 and the value of the CR 16, 141. No different from before, about the influence on the customer's commitment, customer relationship variable is also having a dominant influence on Sharia Banking customer commitment.

Customer relationships are proven to have significant influence on Sharia Banking customer commitment. Where keeping in touch with customers' needs to get special attention from the management [10], of which these conditions due to good marketing relationships with customers will affect the emotional condition who was born of a good relationship [11]. Further, the relationship with customers will take place if the customers feel fulfilled their needs when they are closely related to a company, which in this case is the Sharia Banking Conditions also proven statement. [12] in his research, to mention that relationship marketing to customers has a close relation with the way the service is consistent and timely, so that the company can meet the expectations of the customers. Later, when these conditions can occur in sustainable then directly will provide a positive impact towards customer satisfaction and customer trust at products that are offered by the company, and also surely will give a positive effect on an increase in the profit of the company [13].

\section{CONCLUSION \& SUGGESTIONS}

The variable Profit sharing has proven significant effect on customer trust, of the three indicators that describe how profit sharing, proven indicators (PR2) explaining that the determination of profit sharing deposit products of Sharia Banking consider profit sharing average of other similar deposit products is an indicator of the most influencing customer trust. That is, the better our competitive profit sharing offered by Sharia Banking, it will increase the trust of customers to keep buying the product of Sharia Banking. This condition also provides information that profit sharing deposit products of Sharia Banking has to offer or circulate the market already refers to the standard profit-sharing sharia banking products so that consumers do not feel aggrieved from the profit sharing and of course this will provide a positive impact on the satisfaction of the profit-sharing that will ultimately affect the trust of customers to keep buying the product on Sharia Banking.

Proven customer relationship has significant influence on customers' trust, the four indicators that describe the customer relationships, proven indicators (CR1) which explains that relations with companies of Sharia Banking is an indicator of the most influencing customer trust. That is, the better the relationship built between the Sharia Banking with customers, then it will increase the trust of the customer in buying products in the Sharia Banking. This condition also provides information that the relations between corporate customers by Sharia Banking has resulted in benefits to customers, such as getting the ease of transaction in which the relations with customers, the company will be easier, controlling or managing partner company/customers so that the Sharia Banking can maintain the customer satisfaction that ultimately can improve the sense of desire to commit with the Sharia Banking.

The variable Profit sharing proved to have significant influence on consumer commitment, the three indicators that describe how profit sharing, proven indicators (PR2) explaining that the determination of profit sharing deposit products Sharia Banking consider profit sharing average of other similar deposit products is an indicator that most affect consumer commitment. That is, the more competitive profit sharing has to offer, then it will increase consumer commitment at Sharia Banking.

Proven customer relationship has significant influence on customer commitment. That is, the better the customer relationships it will increase consumer commitment at Sharia Banking. These conditions provide information that customer relationships are built by Sharia Banking is a relationship that is very valuable to customers, with which the Sharia Banking relations that positively make parties Sharia Banking standards better service again in order to maintain the relationship and of course this also in order to maintain a mutual commitment between the Sharia Banking with customers, so that the quality of the give will be very guarded by Sharia Banking company.

Customers trust is proven to have significant influence on consumer commitment, the three indicators that describe the customer trust, proven indicators (KP2) explaining that enhance customer relationships with Sharia Banking requires time and resources are allocated to its customers is an indicator that most affect consumer commitment. This means that the higher the customer trust, then it will increase consumer commitment at Sharia Banking. This condition can also be interpreted that the existence of keeping quality products produced will be able to keep the customers to keep making transactions on Sharia Banking as well as providing customer commitment with products offered by Sharia Banking.

\section{REFERENCES}

[1] Divya Mittal , Shiv Ratan Agrawal , (2016) "The effects of traditional practices on modern banking system", International Journal of Bank Marketing, Vol. 34 Iss: 4, pp.476 - 500 
[2] Bricci, L, A. Fragata, and J. Antunes (2016). Effect of Trust, Commitment and Satisfaction on Customer Loyalty in the Disribution Sector. The Journal of Ecom=nomics, Business and Management, Vol. 4, No. 2, Febrary 2016.

[3] Shahrami, Rarisa, Mojtaba Maleka, Hossein Najafi, and Mohsen Taherkhani. (2016). Investigation the Effectiveness of Relationship Marketing Strategies in Sepah Bank. The Caspian Sea Journal. Volume 10, Issue 1, Supplement 1 (2016) 40-45.

[4] Ernes Yaw Tweneboah-Koduah and Augustine Yuty Duweh Farley. (2016). Relationship between Customer Satisfaction and Customer Loyalty in the Retail Banking Sector og Ghana. International Journal of Business and Management; Vol 11. No. 1; 2016. Canada Center of Science and Education..

[5] Walid Chaouali, Imene Ben Yahia, and Nizar Soulden. (2016). The interplay of counter-conformity motivation, social influence, and trust in customers' intention to adopt internet banking serivices: The case of an emerging country. Journal of Retailing and Consumer Services. Volume 28; January 2016, Pages 209-218.

[6] Sue Greener. (2008). Business Research Methods. Dr. Sue Greener \& Ventus Publishing ApS.

[7] Malhotra, Naresh k. (2007). Marketing Research (15th ed). New Jersey: Pearson Education.

[8] Supranto, j., and Nandan Limakrisna,. (2012). practical guidance the scientific research To craft a thesis, thesis, and dissertation. Jakarta: Media Discourse Partners.

[9] Hair, J.F., Black, W.C., Babin, B.J., Anderson, R.E., and Tatham, Ronald 1. (2006). Multivariate Data Analysis (4th ed.). New Jersey: Pearson Education.

[10] Joe Choon Tean Chai, Narest K Malhotra, and Frank Alpert. (2015). A two-dimesional model of trust-value-loyalty in service relationship. Journal of Retailing and Consumer Services. Volume 26, September 2015, Pages 23-31.

[11] Mostafa Babaeian Jelodar, Tak Wing Yiu, and Suzanne Wilkinson. (2016). A conceptualisation of relationship quality in construction procurement. International Journal of Project Management, vol. 34, Issue 6, pp. 997-1011.

[12] Iram Naz, Syed Muhammad Amir Shah, and Ali M Kutan,. (2016). Do managers of sharia-compliant firms have distinctive financal styles? Journal of International Financial Market Institution and Money. Sounthem Illionis Universtity Edwardsvile, USA.

[13] Lujun Su, Scott R Swanson, Sydney Chichanachahokchai, Maxwell K Hsu, and Xiaohng Chen (2016). Reputation and intentions: The role of satisfaction, identification, and commitmnet. Journal of Business Research, Vol. 69, pp. 3261-3269. 